\title{
Chapter 12 \\ Article 17: The Right to Access to Diverse Sources of Information
}

\author{
Gerison Lansdown
}

States Parties recognize the important function performed by the mass media and shall ensure that the child has access to information and material from a diversity of national and international sources, especially those aimed at the promotion of his or her social, spiritual and moral well-being and physical and mental health. To this end, States Parties shall:

(a) Encourage the mass media to disseminate information and material of social and cultural benefit to the child and in accordance with the spirit of article 29;

(b) Encourage international co-operation in the production, exchange and dissemination of such information and material from a diversity of cultural, national and international sources;

(c) Encourage the production and dissemination of children's books;

(d) Encourage the mass media to have particular regard to the linguistic needs of the child who belongs to a minority group or who is indigenous;

(e) Encourage the development of appropriate guidelines for the protection of the child from information and material injurious to his or her well-being, bearing in mind the provisions of articles 13 and 18.

G. Lansdown $(\bowtie)$

Carleton University, Ottawa, ON, Canada 


\section{What Did Children Say?}

'Informing students of reliable sources/websites; and how to critique news.' (Western Europe/Other)

'The opportunity to have access to information, libraries, schools, websites in order to, we quote, "be smart and know what to say."' (Eastern Europe)

If it is a big business, we will need our council representing government to provide us electricity or bigger generator with data service to be online always. (Africa)

'Website blocking'; 'safety settings'; 'Block harmful sites.' (Western Europe/Other)

\section{Overview}

Although linked closely with Article 13, the right to freedom of expression, Article 17 introduces a unique focus on the role of the mass media in relation to children's rights to information (Sacino, 2011). It places a duty on States Parties to ensure general access to information and material from a diversity of sources, rather than guaranteeing access to each individual child. The language employed in Article 17 obliges States Parties to encourage the media to fulfil this goal, and to adopt the necessary measures to support that process.

In its emphasis on the role of non-state actors in the provision of information, and the use of the term 'encourage,' the wording of Article 17 makes clear that it contains no coercive obligation on mass media to ensure access to material (Tobin \& Handsley, 2019, p. 612). In particular, Article 17 encourages action to ensure that children, including those from minority or indigenous groups, have access to information from diverse national and international sources, which are of social and cultural benefit, consistent with the spirit of Article 29, the aims of education. It also places emphasis on sources of information aimed at promoting well-being, and physical and mental health.

Notably, Article 17 originated as a provision to protect children against harmful influences of media (Office of the United Nations High Commissioner for Human Rights and Rädda Barnen (Society: Sweden), 2007, p. 480). However, during the drafting process, it was observed that the media often did more good than harm, and that the article should be constructed positively (Office of the United Nations High Commissioner for Human Rights and Rädda Barnen (Society: Sweden), 2007, p. 481). Accordingly, only the final paragraph refers to the obligation to encourage guidelines to protect children from harmful or injurious material. It is important to note that the Committee has highlighted the degree to which the rapid development of the digital environment since Article 17 was first drafted has had significant impact on the nature of children's engagement with the mass media, regarding both access and protection (2006a, 2014a, 2016, para. 47). 


\section{General Principles}

Article 2 Imposes three key obligations in respect of the mass media and Article 17:

- All children, without discrimination, should have access to mass media, in respect of outreach, language, age, and formats (Hodgkin et al., 2007; UN Committee on the Rights of the Child, 2007, para. 37; UN General Assembly, 1991, para. 62, 2006, Article 21)

- An obligation to ensure that mass media do not portray any groups of children in a discriminatory manner, inconsistent with their human rights ${ }^{1}$

- An obligation to challenge discriminatory or stigmatising stereotypes adverse to children's rights. ${ }^{2}$

Article 3 The balance in Article 17 between the right to access mass media and the right to protection from harm must be meditated by the best interests principle, consistent with Article 3 together with the child's own views and their evolving capacities.

Article 6 The overall focus of Article 17 is directed towards promotion of wellbeing and therefore in line with the obligation to ensure to the maximum extent possible the development of the child.

Article 12 Access to information, including through the mass media, is necessary is to enable children to express their views effectively (UN Committee on the Rights of the Child, 2009, paras. 82-83). In addition, Article 12 implies an obligation to provide children with opportunities to contribute to the development of media initiatives (UN Committee on the Rights of the Child, 1996).

\section{Articles Related or Linked to Article 17}

Article 13 protects freedom of expression that is contingent on the right to information through a diversity of sources.

Article 14 protects the right to freedom of thought, conscience and religion, the exercise of which requires access to information from a wide variety of sources.

Article 16 protects the right to privacy that can be threatened through the media, particularly in the context of the digital environment.

\footnotetext{
${ }^{1}$ See, for example, CRPD (UN General Assembly, 2006, para. 8) and General Recommendation No. 34 adopted by the Committee on Racial discrimination against people of African descent (UN Committee on the Elimination of Racial Discrimination, 2011, para. 30).

${ }^{2}$ See, for example, Day of General Discussion, The Children and the Media (UN Committee on the Rights of the Child, 1996) and General Comment no. 3 (UN Committee on the Rights of the Child, 2003, paras. 16-17).
} 
Article 18 provides that parents have primary responsibility for the care of children. In so doing, they are key to ensuring that children have access to information and to protecting them from harmful exposure.

Article 19, together with Articles 34 and 36, provide the right to protection from exploitation including in the media.

Article 24 provides for the right to the best possible health. The mass media are a key source of potential information relating to health and well-being.

Article 29 elaborates the aims of education which include recognition that children must be prepared for life in a free society and plays a key part in enabling children to access information.

Article 30 protects the rights of minorities who are identified in Article 17 as being entitled to be given particular regard by the mass media.

Article 42 requires that States Parties make the provisions of the Convention widely known, including through mass media.

\section{Relevant Instruments}

No other human rights treaty has a directly comparable provision to Article 17, but the article has close linkages with the following:

UN Universal Declaration of Human Rights (1948), Article 19

International Covenant on Civil and Political Rights (1966), Article 19

UN Convention on the Rights of Persons with Disabilities (2006), Article 21

European Convention on Human Rights (1950), Article 11

American Convention on Human Rights 'Pact of San Jose, Costa Rica' (B-32)

(1978), Article 13

\section{Attributes}

\section{Attribute One: Diversity of Sources and Media}

Article 17 implies that States Parties must ensure all children have access to communications from a diversity of mass media sources including from both public and private sectors. Diversity of sources is the means through which to achieve the goal of diversity of information (UN Committee on the Rights of the Child, 2014b, para. 28). It can include:

- breadth of ownership of media with multiple outlets for both production and dissemination of information

- the range of sources of information encompassing different cultures and perspectives and including media corporations, advertising agencies, publishers, journalists, editors, and producers 
- different types of communication including news, culture, entertainment, literature, music, arts

- different media through which it is available including television, radio, the Internet, digital media including interactive media such as electronic games, social media platforms, newspapers, magazines, and books. (Sacino, 2011)

Article 17 does not impose duties on States Parties to provide information itself or to control the output of information or communications. Doing so would interfere with freedom of expression. Rather, it is to ensure an environment in which the diversity of mass media sources is made available. For example, this necessitates measures to avoid an over-concentration of private ownership of mass media. In the context of the obligation to ensure diversity from international as well as national sources, this also implies encouragement by joining or supporting organisations such as UNESCO or other regional bodies.

\section{Attribute Two: Beneficial Information and Material}

Whereas Attribute One focuses on the diversity of mass media, Attribute Two focuses on content. The Committee has observed that the mass media, including advertising and marketing industries, can have positive as well as negative impacts on children's rights (2013a, para. 58). Article 17 emphasises the role of mass media in ensuring the provision of information and material aimed at the promotion of social, spiritual, and moral well-being and physical and mental health.

This focus is reinforced in paragraph (a), which encourages dissemination of information and material of social and cultural social benefit to the child. The obligation with regard to content has been interpreted by the Committee to require States Parties to encourage mass media, both online and offline, to provide information necessary for the realisation of rights. This includes:

- promoting the values and aims of Article 29, including fostering understanding, peace and tolerance, and the optimum development of the child (UN Committee on the Rights of the Child, 2001, para. 21)

- promoting access to accurate and adequate information to support health and healthy lifestyles, including that relating to sexual and reproductive health (UN Committee on the Rights of Persons with Disabilities, 2016, para. 26)

- avoidance of promotion of material that violates children's rights through propagation of, for example, discrimination, racism, or misogyny. ${ }^{3}$

The Committee has also emphasised the role the mass media can play in raising awareness of the Convention, monitoring implementation of children's rights,

\footnotetext{
${ }^{3}$ See, for example, CRPD (UN General Assembly, 2006, Article 8, para 2) and General Comment no. 15 (UN Committee on the Rights of the Child, 2013b, para. 84).
} 
producing programmes that are of educational and cultural value for children and facilitating access to and participation of children in the media (1996, 2014a).

\section{Attribute Three: Access to Mass Media}

Information through mass media needs to be available, relevant, and accessible for children, in all environments and settings, through language, outreach, age, and formats. Paragraph (c), for example, draws attention to the need for production and dissemination of children's books and paragraph (d) highlights the importance of having regard to the linguistic needs of minority groups of children. The Committee has highlighted that media, including through the Internet, must be accessible to children of all ages, those from rural and indigenous communities, children with different first languages, children in detention, and children with disabilities. ${ }^{4}$ Availability of libraries is a key means of promoting access (UN Committee on the Rights of the Child, 2000, paras. 42-43).

In addition, States Parties should encourage opportunities for children to have direct access to the media as active participants and initiators, as a means of exercising their Article 12 rights, and to promote their optimum development. Children should not only be able to consume information material but also to have access to opportunities to participate themselves in the media (UN Committee on the Rights of the Child, 1996, 2006a, para. 36).

\section{Attribute Four: Protection from Harmful Material}

Article 17 paragraph (e) requires that States Parties encourage the development of guidelines for the protection of children from material harmful to their well-being. In this context, the nature or level of protection must be assessed with regard to the best interests of children, taking into account their evolving capacities and level of maturity (UN Committee on the Rights of the Child, 2013c). Notably, the language of encouragement implies not that States Parties themselves undertakes this task, but that they encourage others to do so. Furthermore, by referring to guidelines, it implies voluntary rather than legislative controls (Hodgkin et al., 2007). Importantly, it references Articles 13 and 18. In other words, it can be understood that any controls over censorship of the mass media would rely on the limitations imposed in Article 13 paragraph 2, rather than on Article 17.

The reference to Article 18 implies that it is primarily parents rather than the state who have responsibility for ensuring the protection of children from inappropriate or

\footnotetext{
${ }^{4}$ See, for example, Concluding Observations for Central African Republic (2000, paras. 42-43), Greece (2002, paras. 46-47), and Myanmar (2004, paras. 36-37).
} 
harmful media. However, the Committee has repeatedly raised concerns about easy availability of inappropriate or offensive material and recommended that States Parties take all necessary measures to limit exposure of children, particularly in the digital environment, and protect them from such material (1996, 2006b, para. 35). ${ }^{5}$ Providers of digital services should be encouraged to introduce measures such as parental controls, filtering systems, moderation and labelling of content, while ensuring that such provisions do not violate the child's freedom of expression and privacy.

It can be argued that, although recommendations seeking to impose obligations on States Parties appear to exceed the requirements embodied in Article 17, they are legitimate when taken in conjunction with Articles 3, 6, 19 and 24 (Tobin \& Handsley, 2019, p. 633). The Committee has also argued that States Parties should facilitate the involvement of children themselves in the development of protective guidelines (2014a). States Parties should also adopt measures to support and empower children to understand the risks and adopt strategies to avoid harm.

\section{References}

Hodgkin, R., Newell, P., \& UNICEF. (2007). Implementation handbook for the convention on the rights of the child (3rd ed.). UNICEF. Retrieved September 21, 2020, from https://digitallibrary. un.org/record/620060? $\mathrm{ln}=$ en

Office of the United Nations High Commissioner for Human Rights \& Rädda barnen (Society: Sweden). (2007). Legislative history of the convention on the rights of the child. United Nations. https://digitallibrary.un.org/record/602462? $\mathrm{ln}=\mathrm{en}$

Sacino, S. (2011). A commentary on the United Nations convention on the rights of the child, article 17: Access to a diversity of mass media sources. Brill Nijhoff. Retrieved October 25, 2020, from https://brill.com/view/title/11633

Tobin, J., \& Handsley, E. (2019). Article 17: The mass media and children: Diversity of sources, quality of content, and protection against harm. In J. Tobin (Ed.), The UN convention on the rights of the child: A commentary (pp. 600-645). Oxford University Press.

UN Committee on the Elimination of Racial Discrimination. (2011). General recommendation no. 34 adopted by the Committee: Racial discrimination against people of African descent, 2011, $C E R D / C / G C / 34$. UN. Retrieved October 26, 2020, from http://digitallibrary.un.org/ record/714927

UN Committee on the Rights of Persons with Disabilities. (2016). General Comment No. 4 (2016), Article 24: Right to inclusive education, September 2, 2016, CRPD/C/GC/4. Retrieved October 12, 2020, from https://digitallibrary.un.org/record/1313836? $\mathrm{ln}=\mathrm{en}$

UN Committee on the Rights of the Child. (1996). Day of general discussion: The child and the media. UN. Retrieved October 25, 2020, from https://www.ohchr.org/EN/HRBodies/CRC/ Pages/DiscussionDays.aspx

UN Committee on the Rights of the Child. (2000). Concluding observations: Central African Republic, October 18, 2000, CRC/C/15/Add.138. UN. Retrieved October 26, 2020, from http:// digitallibrary.un.org/record/429820

\footnotetext{
${ }^{5}$ See also, for example, Concluding observations for Albania (2012, para. 38) and Australia (2005, para. 34).
} 
UN Committee on the Rights of the Child. (2001). General Comment No. 1 (2001) Article 29 (1): The Aims of Education, April 17, 2001, CRC/GC/2001/1. Retrieved October 10, 2020, from https://digitallibrary.un.org/record/447223? $\mathrm{ln}=\mathrm{en}$

UN Committee on the Rights of the Child. (2002). Concluding observations: Greece, April 2, 2002, CRC/C/15/Add.170. UN. Retrieved October 26, 2020, from http://digitallibrary.un.org/record/ 473476

UN Committee on the Rights of the Child. (2003). General Comment No. 3 (2003) HIV/AIDS and the rights of the child, March 17, 2003, CRC/GC/2003/3. Retrieved October 12, 2020, from https://digitallibrary.un.org/record/501529? $\mathrm{ln}=\mathrm{en}$

UN Committee on the Rights of the Child. (2004). Concluding observations: Myanmar, June 30, 2004, CRC/C/15/Add.237. UN. Retrieved October 26, 2020, from http://digitallibrary.un. org/record/536569

UN Committee on the Rights of the Child. (2005). Concluding observations: Australia, October 20, 2005, CRC/C/15/Add.268. UN. Retrieved October 26, 2020, from http://digitallibrary.un. org/record/569889

UN Committee on the Rights of the Child. (2006a). Day of general discussion: The right of the child to be heard. Retrieved October 12, 2020, from https://www.ohchr.org/EN/HRBodies/CRC/ Pages/DiscussionDays.aspx

UN Committee on the Rights of the Child. (2006b). General Comment No. 7 (2005) Implementing child rights in early childhood, September 20, 2006, CRC/C/GC/7/Rev.1. Retrieved October 12, 2020, from https://digitallibrary.un.org/record/584854? $\mathrm{ln}=\mathrm{en}$

UN Committee on the Rights of the Child. (2007). General Comment No. 9 (2006) The rights of children with disabilities, November 13, 2007, CRC/C/GC/9. Retrieved October 12, 2020, from https://digitallibrary.un.org/record/593891? $\mathrm{ln}=\mathrm{en}$

UN Committee on the Rights of the Child. (2009). General Comment No. 12 (2009) The right of the child to be heard, July 20, 2009, CRC/C/GC/12. Retrieved October 12, 2020, from https:// digitallibrary.un.org/record/671444? $\mathrm{ln}=\mathrm{en}$

UN Committee on the Rights of the Child. (2012). Concluding observations: Albania, December 7, 2012, $C R C / C / A L B / C O / 2-4$. UN. Retrieved October 26, 2020, from http://digitallibrary.un. org/record/739974

UN Committee on the Rights of the Child. (2013a). General Comment No. 16 (2013) on State obligations regarding the impact of the business sector on children's rights, April 17, 2013, $C R C / C / G C / 16$. Retrieved October 12, 2020, from https://digitallibrary.un.org/record/778525? $\ln =\mathrm{en}$

UN Committee on the Rights of the Child. (2013b). General Comment No. 15 (2013) on the right of the child to the enjoyment of the highest attainable standard of health (art. 24), April 17, 2013, $C R C / C / G C / 15$. UN. Retrieved October 26, 2020, from http://digitallibrary.un.org/record/ 778524

UN Committee on the Rights of the Child. (2013c). General Comment No. 14 (2013) On the right of the child to have his or her best interests taken as a primary consideration (art. 3, para. 1), May 29, 2013, $C R C / C / G C / 14$. Retrieved October 12, 2020, from https://digitallibrary.un.org/record/ $778523 ? \ln =$ en

UN Committee on the Rights of the Child. (2014a). Day of general discussion: Digital media and children's rights. UN. Retrieved October 24, 2020, from https://www.ohchr.org/EN/HRBodies/ CRC/Pages/Discussion2014.aspx 
UN Committee on the Rights of the Child. (2014b). Concluding observations: Hungary, October 14, 2014, CRC/C/HUN/CO/3-5. Retrieved October 11, 2020, from https://digitallibrary.un.org/ record $/ 793888 ? \ln =$ en

UN Committee on the Rights of the Child. (2016). General Comment No. 20 (2016) on the implementation of the rights of the child during adolescence, December 6, 2016, CRC/C/GC/ 20. Retrieved October 12, 2020, from https://digitallibrary.un.org/record/855544? $1 \mathrm{n}=\mathrm{en}$

UN General Assembly. (1991). United Nations rules for the protection of juveniles deprived of their liberty, 1990, A/RES/45/113 (The Havana Rules). UN. Retrieved October 26, 2020, from http:// digitallibrary.un.org/record/105555

UN General Assembly. (2006). Convention on the rights of persons with disabilities, 2006, A/RES/ 61/106. Retrieved May 3, 2020, from https://digitallibrary.un.org/record/588742? $\ln =\mathrm{en}$

Open Access This chapter is licensed under the terms of the Creative Commons Attribution 4.0 International License (http://creativecommons.org/licenses/by/4.0/), which permits use, sharing, adaptation, distribution and reproduction in any medium or format, as long as you give appropriate credit to the original author(s) and the source, provide a link to the Creative Commons license and indicate if changes were made.

The images or other third party material in this chapter are included in the chapter's Creative Commons license, unless indicated otherwise in a credit line to the material. If material is not included in the chapter's Creative Commons license and your intended use is not permitted by statutory regulation or exceeds the permitted use, you will need to obtain permission directly from the copyright holder.

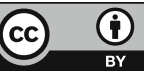

